\title{
Dynamic padding by retrofit airbags and knee bars. A study of Swedish mail delivery cars
}

\author{
Mats Öström ${ }^{a, b}$, Anders Eriksson ${ }^{a}$, Jan Thorson ${ }^{c}$, David J. Romeo ${ }^{d}$ and Leif \\ Svensson ${ }^{\mathrm{e}}$ \\ ${ }^{a}$ Department of Forensic Medicine, University of Umeå, P.O. Box 7642, S-907 12 Umeå, \\ Sweden \\ ${ }^{\mathrm{b}}$ University of Michigan Transportation Research Institute, 2901 Baxter Road, Ann Arbor, MI \\ 48109-2150, USA \\ 'Ansvar Insurance Company, P.O. Box 5071, S-102 42 Stockholm, Sweden \\ ${ }^{\mathrm{d}}$ Romeo Engineering International Incorporated, 418 Prince Road, Temple, AZ 85281, USA \\ -Hedemora Bilteknik AB, Bivägen 34, S-776 00 Hedemora, Sweden
}

(Received 13 March 1991; accepted 10 February 1992)

\begin{abstract}
Öström, M., Eriksson, A., Thorson, J., Romeo, D.J. and Svensson, L., 1992. Dynamic padding by retrofit airbags and knee bars. A study of Swedish mail delivery cars. Safety Science, 15: 147154.

The present study demonstrates the feasibility of a retrofit driver airbag system and knee bars in passenger cars for mail delivery. The system was tested in field experiments, in rough road test, and in low and high speed barrier test. No faults of the system occurred and the crash tests revealed that the energy reducing capacity in frontal collisions was satisfactory. As airbags prevent injuries to non-belt-users, such as certain occupational drivers, we advocate a wider implementation of retrofit airbag systems. We also stress the importance of using seat belts in conjunction with airbags.
\end{abstract}

\section{Résumé}

Cette étude démontre la faisabilité de la mise en place du système de conduite avec coussin d'air monté après construction et barres de protection pour les genuux dans les vuitures de courisme affectées à la distribution du courrier. Le système a été testé sur le terrain, il a subi des tests sur route très difficiles ainsi que des tests de collision frontale à vitesse élevée et basse. Aucun défaut n'a pu ĉtre détecté sur le système et les tests de collision ont révelé que la capacité de réduction d'énergie au cours des collisions frontales était satisfaisante. Etant donné que les coussins d'air évitent des blessures aux personnes qui ne s'attachent pas en voiture, comme c'est souvent le cas pour celles qui sont chauffeur/livreur, nous conseillons et souhaitons vivement que le système à coussin d'air retrofit puisse être mis en place à très large échelle. Nous mettons également l'accent sur l'importance de l'utilisation des ceintures en combinaison avec les coussins d'air.

Correspondence to: Anders Eriksson, Department of Forensic Medicine, University of Umeå, P.O. Box 7642, S-907 12 Umeå, Sweden. 


\section{Zusammenfassung}

Diese Untersuchung liefert den Beweis für die Durchfuhrbarkeit eines nachträglich einzubauenden Luftsackes und Kniestangen in Personenkraftwagen für die Zustellung der Post. Dieses Sicherheitssystem wurde in der Praxis unter schweren Straßenverhältnissen sowie durch Anprallversuche mit niedriger und hoher Geschwindigkeit getestet. Das Sicherheitssystem wies keine Defekte auf, während die Anprallversuche eine befriedigende Verringerung der Energie bei Frontalzusammenstößen ergab. Da durch Luftsäcke Verletzungen bei nichtangeschnallten Insassen wie bestimmten Berufsfahrern vermieden werden, befürworten wir eine allgemeinere Einführung von nachträglich einzubauenden Luftsäcken. Weiter möchten wir betonen, daß die Benützung von Sicherheitsgurten zusammen mit Luftsäcken von großer Wichtigkeit ist.

\section{Introduction}

Injuries from traffic crashes have become one of the main causes of severe handicaps and lost work-years among industrialized countries, especially due to their high involvement of young people (Committe on Trauma Research, 1985). Motor vehicle crashes are responsible for between $30 \%$ and $40 \%$ of all injury deaths during occupational activities in the United States (Baker et al., 1976, 1982; Karlsson and Baker, 1978; Kraus, 1985) as well as about $12 \%$ of all occupational non-fatal injuries (Runyan and Baker, 1988).

In fact, traffic crashes are one of our most important major public and occupational health problems, and the search for preventive measures must be given high priority. Such measures have included improvements in the traffic environment and vehicle safety. However, during the late $80 \mathrm{~s}$, the number of traffic injuries and fatalities has increased in Sweden, and each year about 800 persons loose their lives in traffic crashes (Official Statistics of Sweden, 1989), with many more severely injured. We thus feel there is a need for further attempts to increase traffic safety.

A possible strategy to increase the interior protection of the vehicle is to supplement the seat belt with a passive dynamic padding system, such as an airbag and knee bar. This measure is especially desirable for passenger car occupants who do not use seat belts in spite of the risk of collision. Such a group is represented by certain occupational drivers.

As about one-third of all collisions are frontal, and injuries are most often caused by the windshield or the steering wheel in Swedish vehicle-related occupational injuries (Romeo et al., 1987), we have in the present paper analyzed the function of a retrofit driver airbag system with a knee bar in two passenger cars used for mail delivery. We also report on the function of the system on the road and in simulated frontal crashes. 


\section{Material and methods}

An airbag system (for details see Romeo and Morris, 1984) was installed in two 1985 Opel Kadett vehicles at the Hedemora Bilteknik AB, Hedemora, Sweden, by Romeo Engineering International Inc. A knee bar for control of lower torso kinematics and injury protection was mounted below the instrument panel on the driver side at the same time.

Initially, the crash sensors were located relatively far forward in the engine compartment. This location, as well as a location of the sensor just behind the shock towers (hereafter referred to as front and aft sensor locations), were evaluated by sensor threshold barrier tests.

\subsection{Installation}

In the engine compartment, the system consisted of two front crash sensors, which were mounted in the frontal crash zone of the vehicle. A low level sensor (less than 2-3 g) in series with each front sensor, to help preventing inadvertent deployment, was located at the fire wall. In addition to connecting the front sensors, a protective wiring harness had wiring to power and ground and a readiness indicator light. The wiring went up the steering column through a coiled connector to a four-spoke airbag steering wheel. The airbag system was active only when the ignition was on. The airbag module consisted of a gas generator, a neoprene coated nylon airbag, metal mounting components and a reinforced cover assembly (see Romeo and Morris, 1984, for details).

A knee bar was mounted just below the instrument panel on the driver side. It consisted of $1 \mathrm{~mm}$ thick sheet metal, energy absorbing foam, and a vinyl cover and as designed to fit each individual car.

Evaluation of the installed driver airbag system was conducted through a series of tests: field experience, rough road tests, sensor threshold barrier tests, and airbag performance evaluation by frontal barrier crash tests.

\subsection{Field experience}

As part of the project, the two test vehicles were road tested on an actual post office delivery route over a period of four months (November-March).

\subsection{Rough road tests}

A series of rough road tests was conducted by driving the vehicle at increasing speeds from $20 \mathrm{~km} / \mathrm{h}$ to $50 \mathrm{~km} / \mathrm{h}$ over a $10 \mathrm{~cm}$ high curb and at $30 \mathrm{~km} / \mathrm{h}$ and $40 \mathrm{~km} / \mathrm{h}$ over a $12.7 \mathrm{~cm}$ high curb. During these tests, the gas generator was replaced with a flash bulb so that any front sensor closure would fire the flash bulb rather than deploy the airbag. 


\subsection{Sensor threshold barrier tests}

Four frontal barrier tests (see Table 1) were performed in order to provide sensor closure data. Tests were run at 10,12, 20 and $50 \mathrm{~km} / \mathrm{h}$. Four sensor accelerometer package locations were tested fore and aft.

Sensor closure occurred for the right front sensor at impact speeds of 9.5 and $11.7 \mathrm{~km} / \mathrm{h}$ (Table 1 ). Therefore, the aft location was selected and used in the airbag performance crash tests.

\subsection{Crash test}

Two full frontal barrier crash tests were conducted at impact velocities of 40 and $49 \mathrm{~km} / \mathrm{h}$ at the Swedish Road and Traffic Institute, Linköping, Sweden (Table 2).

\section{TABLE 1}

Sensor closure time at different speeds

\begin{tabular}{lllll}
\hline Speed $(\mathrm{km} / \mathrm{h})$ & \multicolumn{2}{l}{ Sensor closure time $(\mathrm{ms})$} & \\
\cline { 2 - 5 } & \multicolumn{2}{l}{ Front } & Aft & \\
\cline { 2 - 4 } & Left & Right & Left & Right \\
\cline { 2 - 4 } & No & 47 & No & No \\
11.7 & No & 40 & No & No \\
19.8 & 21 & 25 & 23 & 28 \\
49.8 & 9 & 9 & 11 & 10 \\
\hline
\end{tabular}

\section{TABLE 2}

The results of crash tests using the US Federal Motor Vehicle Safety Standard 208 set-up, compared to the tolerable limits at $30 \mathrm{mph}(48.3 \mathrm{~km} / \mathrm{h})$ (NHTSA, 1989b)

\begin{tabular}{lccc}
\hline & $\begin{array}{l}\text { Test } 1 \\
(39.5 \mathrm{~km} / \mathrm{h})\end{array}$ & $\begin{array}{l}\text { Test } 2 \\
(48.9 \mathrm{~km} / \mathrm{h})\end{array}$ & $\begin{array}{l}\text { US FMVSS } \\
(48.3 \mathrm{~km} / \mathrm{h})\end{array}$ \\
\hline $\begin{array}{l}\text { Head injury criteria' } \\
\text { value) }\end{array}$ & 560 & 688 & 1000 \\
Chest resultant acceleration ( $)$ & 40 & 48 & 60 \\
Left femur (lbs) & 1078 & 1738 & 2250 \\
Right femur (lbs) & 704 & 1276 & 2250 \\
\hline
\end{tabular}

${ }^{1} \mathrm{HIC}$ is a universally accepted nondimensional integrated acceleration time history of the resultant acceleration of the dummy head. A value of 1000 is considered the threshold of moderate to serious injury. 


\section{Results}

\subsection{Field experience}

Each of the mail cars accumulated a mileage of $20000 \mathrm{~km}$ during the four months of testing. No faults occurred in the system.

\subsection{Rough road test}

No front sensor closures occurred in these tests.

\subsection{Sensor threshold barrier tests}

Since prior to testing it was believed that sensor closures would not occur at speeds below $12 \mathrm{~km} / \mathrm{h}$, the first test was run at $11.7 \mathrm{~km} / \mathrm{h}$. However, the right front sensor closed $40 \mathrm{~ms}$ after the crash. Thus, a second test at $9.8 \mathrm{~km} / \mathrm{h}$ was run which also resulted in sensor closure on the right side for the forward location, this time at $47 \mathrm{~ms}$.

A third test conducted at $19.8 \mathrm{~km} / \mathrm{h}$ produced sensor closure times, i.e. the time from crash initiation to closure of the sensor contacts, for all four sensors ranging between 21 and $28 \mathrm{~ms}$. The aft location resulted in a delay of $2-3 \mathrm{~ms}$.

Based upon occupant kinematics and bag deployment time, a sensor closure time of $20 \mathrm{~ms}$ or less was desired for the $49 \mathrm{~km} / \mathrm{h}$ test condition. Thus, a test was also run at this speed. Acceptable closure times at all locations were registered, with only a 1-2 ms delay between front and aft locations (Table 1). In Fig. 1, sensor closure time of the right front sensor location is plotted as a function of impact velocity.

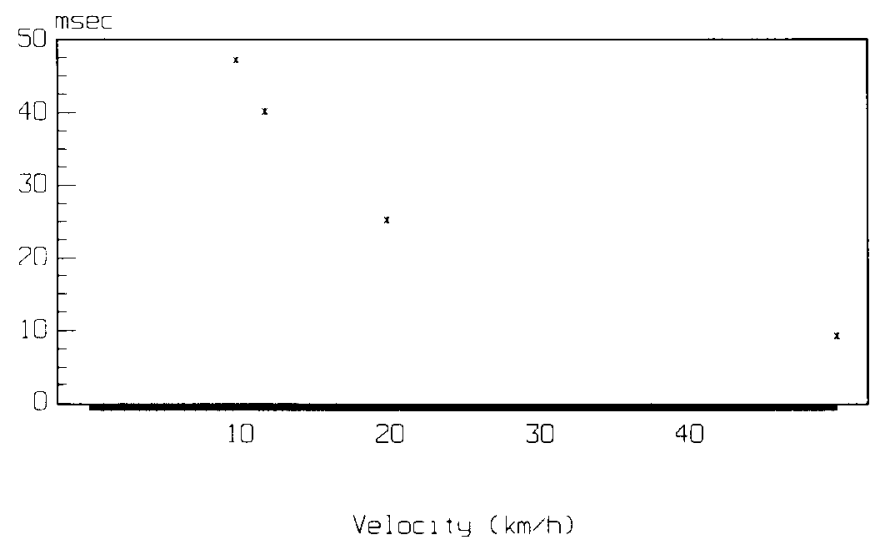

Fig. 1. Sensor closure time (ms) of the right front as a function of impact velocity $(\mathrm{km} / \mathrm{h})$. 


\subsection{Crash test}

The first test was conducted with an actual crash speed of $39.5 \mathrm{~km} / \mathrm{h}$ using an unbelted 50 th percentile driver dummy (NHTSA, 1989b) set-up. The sensor closure time was $12-14 \mathrm{~ms}$. A second crash under the same test dummy setup conditions was performed at an impact speed of $48.9 \mathrm{~km} / \mathrm{h}$ (Table 2 ). Both crashes produced dummy results well within the tolerance limits (NHTSA, 1989b).

\section{Discussion}

Improvement of traffic safety has been seen both in the road environment and in the interior protection of passenger vehicles. One of the most effective safety measures is the three-point seat belt. Being compulsory in Sweden, the use of seat belts is about $90 \%$ among front seat occupants (Lacko and Nilsson, 1988), but considerably lower among high-risk occupants. In occupations where the driver has to leave the vehicle frequently, such as mail carriers and taxi drivers, the seat belt can be a source of irritation and is, therefore, used less often. Such problems are not associated with the use of airbags (Jagger et al., 1987 ). Moreover, the seat belt does not protect against injuries caused by broken windshields or by objects within the passenger compartment. Occasionally, the belt itself can cause trauma to the vehicle occupant, particularly when used improperly (Green et al., 1986; Katz et al., 1987; Sato, 1987; States et al., 1987).

In the present paper we have discussed the possible benefits of a driver-side airbag in small-size cars, as a means to enhance interior safety in frontal crashes. While seat belts protect vehicle occupants from ejection (Evans, 1990; Green et al., 1987) and contact with the vehicle interior by restraining, the dynamic padding of airbags reduces the amount of kinetic energy involved in occupant impacts with the vehicle interior, thereby reducing injuries.

The effectiveness of airbags for reducing the number of fatalities among unbelted drivers has been reported to be about 20\% (Green et al., 1987; Wilson and Savage, 1973), and the effectiveness for reducing severe injuries is about the same (Pursel et al., 1978). The National Highway Traffic Safety Administration (1984) estimatcd a $5 \%$ increase in effectiveness if a lap-shoulder belt and airbag are used together compared to the effectiveness of a lap-shoulder belt alone. Our present study confirms that an airbag provides a considerable amount of protection in frontal collisions (Jagger et al., 1987; Mertz, 1978; Evans, 1990), which is the most common collision type among fatally-injured, unbelted drivers (NHTSA, 1989b).

No front sensor closures occurred in our field experiments. The curb tests were not severe enough to ensure that the sensors would not close in a test up 
to the limit of potential occupant injury. Nevertheless, these tests certainly strengthen the belief that unwanted deployments due to rough driving would not occur in routine use (Backaitis and Roberts, 1987).

Furthermore, the feasibility of installation of a retrofit driver airbag system was satisfactorily demonstrated. In fact, the system easily met the United States Federal Motor Vehicle Safety Standards for automatic or passive restraints (NHTSA, 1984). This result suggests the possibility of mandating airbags to be manufactured with retrofit in all passenger cars. At least cars used for occupational transportation should be the subject of such a mandate since safety standards are higher for work environments than for private ones and economic resources are greater for employees than for employers.

Currently, airbag technology represents the most promising part of a riskreducing program geared towards motor vehicle injuries. Airbags are of primary interest for reducing injuries to car occupants. Currently, they offer protection in frontal collisions, but they will soon apply to other types of impact as well. They supplement the initiatives of the individual, primarily the use of manual seat belts. In the case of no seat belt use, an airbag contributes substantially to injury risk reduction.

There has been speculation that individuals protected by an airbag might be less likely to use their seat belt, since they might erroneously (Evans, 1990) assume that the air bag alone will provide sufficient protection. However, belt use of drivers does not drop in cars equipped with air bags (Williams et al., 1990 ). While airbags can reduce injury both among belted and unbelted occupants, the most effective way to prevent injury is the joint use of a lap-shoulder belt and an airbag (Backaitis and Roberts, 1987; Evans, 1990).

\section{Acknowledgement}

This study was supported by grants from Berfenstams stipendiefond, Cancer- och Trafikskadades Riksförbund, Medicinska Forskningsrădet, Motormännens Helnykterhetsförbund, The Swedish Society of Medicine, The Swedish Institute, and the University of Umeå.

\section{References}

Backaitis, S.H. and Roberts, J.V., 1987. Occupant injury patterns in crashes with airbag equipped government sponsored cars. Proc. 31st Stapp. Car Crash Conf., New Orleans, MS, pp. 251266.

Baker, S.P., Samkoff, J.S., Fisher, R.S. and van Buren, C.B., 1982. Fatal occupational injuries. J. Am. Med. Assoc., 248: 692-697.

Baker, S.P., Wong, J. and Baron, R.D., 1976. Professional drivers: Protection needed for a highrisk occupation. Am. J. Publ. Health, 66: 649-654. 
Committee on trauma research, Commission on life sciences, National research council and the Institute of medicine, 1985. Injury in America: A continuing public health problem. National academy press, Washington, DC.

Evans, L., 1990. Restraint effectiveness, occupant ejection from cars, and fatality reductions. Accid. Anal. Prev., 22: 167-175.

Green, P.D., Robertson, N.K.B., Bradford, M.A. and Bodiwala, G.G., 1987. Car occupant ejection in 919 sampled accidents in the UK: 1983-86. In: Restraint technologies: Front seat occupant protection, Soc. Automotive Engineers, Detroit, pp. 91-104.

Green, R.N., German, A., Gorski, Z.M. and Tryphonopoulos, J.P., 1986. Improper use of occupant restraints: case studies from real world collisions. Proc. Am. Assoc. Automotive Med., Montreal, pp. 423-438.

Jagger, J., Vernberg, K. and Jane, J.A., 1987. Air bags: Reducing the toll of brain trauma. Neurosurgery, 20: 815-817.

Karlson, T.A. and Baker, S.P., 1978. Fatal occupational injuries associated with motor vehicles. Proc. Ann. Meet. Am. Assoc. Automotive Med., pp. 229-241.

Katz, E., Grosch, L. and Kassing, L., 1987. Chest compression response of a modified hybrid III with different restraint systems. Proc. 31st Stapp. Car Crash Conf., New Orleans, MS, pp. 245250 .

Kraus, J., 1985. Fatal and nonfatal injuries in occupational settings: A review. Ann. Rev. Publ. Health, 6: 403-418.

Lacko, P. and Nilsson, G., 1988. Bilbältesanvändning i Sverige 1983-1986, Report no. 326, The Swedish Road and Safety Institute, Linköping.

Mertz, H.J., 1978. Restraint Performance of the 1973-76 GM Air Cushion Restraint System. In: Automatic occupant protection systems, S.H. Backaitis, D.C. Viano (Fds.), Soc. Automotive Engineers, Warrendale, PA, pp. 61-71.

National Highway Traffic Safety Administration, 1984. Final regulatory impact analysis; Amendment of FMVSS 208, Passenger car front seat occupant protection. Washington, DC.

National Highway Traffic Safety Administration, 1989a. FMVSS 208, Occupant Crash Protection. 49 Code of Federal Regulations, part 571.208.

National Highway Traffic Safety Administration, 1989b: Fatal Accident Reporting System 1988, Washington, DOT HS 807507.

Official statistics of Sweden 1988, Traffic Injuries. Statistics Sweden, Stockholm, 1989.

Pursel, H.D., Bryant, R.W., Scheel, J.W. and Yanik Sr, A.J., 1978. Matching case methodology for measuring restraint effectiveness. Technical paper series no 780415, Soc. of Automotive Engineers, pp. 1-31.

Romeo, D.J. and Morris, J.B., 1984. Driver air bag police fleet demonstration program - a 15 month progress report. Technical paper series no 841216, Soc. of Automotive Engineers.

Romeo, D., Svensson, L. and Thorson, J., 1987. Collisions involving passenger cars with driver side air bags - A US-Swedish R\&D-project. In: Roads and Traffic Safety on Two Continents, Gothenburg, pp. 200-212.

Runyan, C.W. and Baker, S.P., 1988. Occupational motor vehicle injury morbidity among municipal employees. J. Occup. Med., 30: 883-886.

Sato, T.B., 1987. Effects of seat belts and injuries resulting from improper use. J. Trauma, 27: $754-758$.

States, J.D., Huelke, D.F., Dance, M. and Green, R.N., 1987. Fatal injuries caused by underarm use of shoulder belts. J. Trauma, 27: 740-745.

Williams, A F., Wells, J.K. and Lund, A.K., 1990. Seat belt use in cars with air bags. Am. J. Publ. Health, 80: 1514-1516.

Wilson, R.A. and Savage, C.M., 1973. Restraint system effectiveness: $\Lambda$ study of fatal accidents. Proc. Automotive Safety Engineering Seminar, Warren, MI, June 20-21, pp. 27-38. 